\title{
Pre-Service Teachers' Comments toward Official Teacher Selection System (Civil Servant Selection Examination, KPSS) in Turkey: A Qualitative Analysis
}

\author{
Ilker Ugulu, Nurettin Yorek ${ }^{*}$ \\ Faculty of Education, Dokuz Eylul University, Izmir, Turkey \\ Email: nyorek@gmail.com
}

Received 14 August 2015; accepted 12 September 2015; published 15 September 2015

Copyright (c) 2015 by authors and Scientific Research Publishing Inc.

This work is licensed under the Creative Commons Attribution-NonCommercial International License (CC BY-NC).

http://creativecommons.org/licenses/by-nc/4.0/

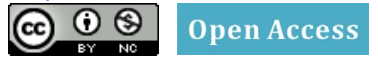

\section{Abstract}

The purpose of this research is to investigate the opinions of the pre-service teachers toward teacher selection system and civil servant selection exam (KPSS). In this study, qualitative research methods and semi-structured interviews were used and researcher-made questionnaires containing open-ended questions were administered. The study group consists of 100 pre-service teachers from four departments (elementary education, biology education, Turkish education, and mathematics education) in Balikesir University (in western Turkey). Pre-service teachers reported that KPSS was not an appropriate examination to select a qualified teacher. Pre-service teachers suggest that both an oral and written examination process should be applied instead of KPSS.

\section{Keywords}

Teacher Selection, Pre-Service Teachers, Opinion, Qualitative Analysis

\section{Introduction}

Although teaching is one of the oldest occupations in human history, it took until 20 century for its transformation into the occupation with characteristics as we know today [1]. According to Erden [2], determination of occupational criteria for teaching brought respect and also effectiveness to the occupation. Today pedagogues, who

*Corresponding author.

How to cite this paper: Ugulu, I. and Yorek, N. (2015) Pre-Service Teachers' Comments toward Official Teacher Selection System (Civil Servant Selection Examination, KPSS) in Turkey: A Qualitative Analysis. Open Journal of Social Sciences, 3, 182-189. http://dx.doi.org/10.4236/jss.2015.39025 
consider education as a social system, accept three main components of education as student, teacher and education program [3]. Researches on place and importance of these components indicate that, teachers have the strategic importance in system. This strategic importance also underlines the occupation of teaching. In a country, education and quality of human power are considered together with qualification of teachers. It is very difficult to speak about a success of teachers who randomly or compulsory enter into system and who are not able to meet personal and occupational expected characteristics for teaching. Because developing technology cannot replace the place of teacher, on the contrary, more qualified teachers who can effectively use technology are needed. Thus, the issue of qualified teachers contains all processes including raising, and employing of teachers. So, issue of quality in education should be considered in our country as it is being questioned globally [4].

In our country, establishment of Darülmüallimin-i Ruşdiye in 1848 and Darülmuallimin-i Sıbyan in 1868 can be considered as the first important steps of reformation efforts of education system. Especially, after declaration of republic, these efforts gained impetus. With approval of “Secondary Education Teachers Law” on 13 March 1924, teachers were defined as members of occupation who were in charge of education and training which was considered one of the general services of state [5]. Again in the same law, conditions of being a teacher were defined. With this law, the name Darulmuallimin was turned into Muallim Mektebi in 1925 and Teachers School in 1935. Later, several methods were applied in order to meet the need of teachers. Gazi Muallim Mektebi, Terbiye Enstitüsü, Balıkesir Muallim Necati Terbiye Enstitüsü were established and elementary school teachers were brought up with Village Teachers Law in 1937. Teachers' gap was tried to be closed by establishing Village Institutions that were opened in 1940 [6].

1739 numbered National Education Principal Law which was approved in 1973, defined the main framework of teaching as a profession as we understand today. This law is especially important since it considered teachers education within the framework of higher education and also opened the doors for accreditation processes in raising teachers [7]. Raising teachers was left to universities in 1982 and Faculties of Education were given the responsibility of raising teachers. Today, there are more than 60 education faculties in our country. Importance of profession of teaching made selection of qualified teachers obligatory [7].

Target of effective selection of teachers is to select the right personnel. Aim of a confident teacher selection period should be to find the personnel with required characteristics. Selection of pre-service teachers at each level and equipping them with necessary professional formation remained important in countries' agenda as it had been in the past [8]-[11]. If we examine the literature about the acceptance of teachers to profession, we see that we generally accept criteria and systems of countries which we also follow their raising teachers methods. Many countries take cautions for improving qualifications of teachers. Referring to Semerci and Özer [7], similar examinations like Public Personnel Selection Examination we apply in teachers' appointments in public are also seen in Germany, Austria, France, Spain, Luxemburg and in some states of USA. These examinations can be in written form as well as interviews like they are applied in Belgium, Greece, Netherlands and Portugal.

In our country, several examinations were applied for selection of teachers. In 1999, Student Selection and Placement Center (ÖSYM) executed an examination (DMS) of selection of public officers for the first time. DMS exam was turned into a central selection examination (KMS) in 2001. A year later, KMS was repealed with "Regulation on Examinations Applied to Ones Who Will Be Appointed to Public Service for the First Time" which was published in Official Gazette on 03.05.2002 with issue number 24744. Student Selection and Placement Center (ÖSYM) united State Officers Examination (DMS) of 2001 and Central Selection Examinations for Institutions (KMS) of 2002 and decided to apply a new examination with the name Public Personnel Selection Examination (KPSS) which pre-service teachers would also attend beginning with 2002. All pre-service teachers in Turkey should attend this KPSS examination after graduating from 4 years of university education [12]. To pass this examination, they have to complete three levels. In the first part, general culture and general skills of pre-service teachers are evaluated in 120 questions. (Categories and shares in general skills are 50\% Turkish, 50\% maths; categories and shares of general culture are 40\% Atatürk's Principles and Revolutions, 15\% Basic Citizenship Information, 5\% Current Social and Economic Issues in Turkey and Globe, 10\% Turkish Culture and Civilizations and 30\% Turkish Geography). In the second part, sufficiency of candidates is evaluated in educational sciences with 80 questions. In the third and final part, candidates attend to teaching branch (ÖABT) exam composed of 50 questions. 40 of the questions of ÖABT are from branch information and 10 are from branch education.

Since execution of state office and public personnel selection examinations, there have been always debates on validity, security, problems in appointment period, scope, categories and their shares of exam. In the center 
of these debates, there stand pre-service teachers either graduated or still in education period. Within this framework, an academic study about the comments of candidate teachers on KPSS examination seems useful in those debates.

\section{Method}

\subsection{Research Model}

In the study, case study method of qualitative research methods is used. One of the main characteristics of qualitative case study is the deeply examination of one or more cases. The main focus of such kind of studies are factors that affect desired case (environment, individuals, events, processes etc.) and how they affect and are affected by the case [13].

\subsection{Working Group}

The study group consists of 100 pre-service teachers from four departments (Elementary education, biology education, Turkish education, and mathematics education) in Balikesir University (in western Turkey). 63 of 100 students are female and 27 are male.

\subsection{Data Collection Tool}

Semi structured interview form prepared by the researcher was used as data collection tool in the study. While preparing interview form, literature on the subject had been evaluated and pre-interviews with five senior students were made. Interview form had been shaped due to the results of these interviews and been examined by two lecturers and finalized. Interview form is composed of open ended questions.

\subsection{Analysis of Data}

While evaluation of data gathered within the framework of this study, content analysis method has been used. The basic activity of content analysis method in which data are detail evaluated is to gather similar data under certain concepts and themes and to arrange and interpret them in such way that readers can easily follow [13].

Voices were recorded during the interviews with participants during study and notes were taken by the researcher during interviews. Later, voice records were transformed into written form and definition and content analysis were made over whole data. Addition to those, direct quotations which reflected special comments and views were taken place. These can be accepted applications in order to increase validity and reliability of the study. To contribute to the validity of the study, researcher focused on establishing long term interaction with pre-service teachers. Yıldırım and Şimşek [13], define that in the first phases of interview, participants are affected by the researcher and only duration of interview extends, researcher can get more valid and healthier information from the participants. Thus, durations of interviews were extended as much as possible in order to contribute to the validity of the study. Also in order to increase validity of the study, gathered data were summarized and participants were asked to confirm those data. To increase validity and reliability of study, variety of researcher method was used [13], data were examined by three different specialists and analysis were made on themes and sub themes on which specialists agreed on. Finally, maximum diversity was tried to be provided while selecting participants so different and specific comments can be obtained.

\section{Findings}

In this section, within the framework of themes and sub themes determined by evaluation of gathered data, views of secondary school students are presented. Student views are analyzed in accordance with tables of themes and sub themes.

\subsection{Views on Preparation for KPSS}

Interviews done within the scope of this study proved that students of senior classes shaped their education and training programs giving priority to preparation to KPSS examinations. This trend is so strong that many of students ignored their lectures in university, only focused on lectures within the framework of KPSS, or attended to several courses in accordance with KPSS exams. Thus, $67 \%$ of the participants chose private teaching institu- 
tions to the question "In the preparation period for KPSS, do you think schools or private teaching institutions are more beneficial?” confirmed this approach (Table 1). Similarly, only $10 \%$ of the students answered this question with the answer of "school". On the other hand, $10 \%$ of participants said "both of them are beneficial" and $13 \%$ of students answered "none of them are beneficial".

Data gathered in study about this question showed that, many of pre-service teachers considered private teaching institutions more beneficial in preparation period for KPSS examinations. Candidates said the reason of this thought basically came from the scope of the examination. Many of the candidates thought the examination required too much theoretically knowledge and most of this information was not relevant with their branch. Thus, most of the candidates prefer private teaching institutions since they encourage organized studying to exams and they provide trial options. Comments of students on this subject are given below:

"Honestly, I believe private teaching institutions are more beneficial in preparation for KPSS examination. I also believe our education system is totally based on examinations. We got prepared for high school, we got prepared for university, and now as teachers we prepare ourselves to another examination to be teachers. Our life is full of exams... (laughing). I believe private teaching institutions are more practical in preparation period for exams." (STUDENT 47)

\subsection{Comments on KPSS Examination}

To exercise teaching profession in full terms, of course pre-service teachers should be equipped with certain skills and equipments. Some of candidate teachers are equipped with these skills while some others are not equipped. Within this framework pre-service teachers are asked whether "KPSS is an obstacle or an opportunity to be recognized?" $89 \%$ of pre-service teachers answered this question as "Exams are obstacles for candidates" while $11 \%$ of them answered the question as "Exam is an opportunity to be recognized for the candidate" (Table 2).

These data confirm that, most of pre-service teachers see KPSS examination as an obstacle on their ways to become teachers. One of the reasons why pre-service teachers consider KPSS examination as an obstacle on their ways to become teachers is the thought of injustice in appointment points. They believe of injustice since some branches are appointment with very high scores while on the other hand some branches are appointed with low scores. Comment of one of the pre-service teachers who delivered similar opinion is given below:

"To me, examination is an obstacle for the ones who want to be teacher. I do not believe this examination is beneficial to select the right ones among the candidates. For instance, I study biology. I am not asked about my branch, then how come this examination chose good biology teachers...” (STUDENT 76)

\subsection{Comments on Necessity of KPSS}

$35 \%$ of pre-service teachers said "Exam is necessary" to the question "Do you believe KPSS is necessary to be

Table 1. Comments of pre-service teachers on KPSS preparation.

\begin{tabular}{cccccc}
\hline Sub-themes & \multicolumn{2}{c}{ Girls } & \multicolumn{2}{c}{ Boys } & \multicolumn{2}{c}{ Total } \\
\cline { 2 - 6 } & $\mathrm{n}$ & $\%$ & $\mathrm{n}$ & $\%$ & $\%$ \\
\hline KPSS preparation courses are more beneficial & 43 & 68.2 & 24 & 65 & 67 \\
Schools are more beneficial & 2 & 3 & 8 & 21.6 & 10 \\
Courses and schools, both are beneficial & 8 & 12.6 & 2 & 5.4 & 10 \\
None isn't beneficial & 10 & 15.8 & 3 & 8.1 & 13 \\
\hline
\end{tabular}

Table 2. Comments of pre-service teachers on KPSS.

\begin{tabular}{|c|c|c|c|c|c|}
\hline \multirow{2}{*}{ Sub-themes } & \multicolumn{2}{|c|}{ Girls } & \multicolumn{2}{|c|}{ Boys } & \multirow{2}{*}{$\begin{array}{c}\text { Total } \\
\%\end{array}$} \\
\hline & $\mathrm{n}$ & $\%$ & $\mathrm{n}$ & $\%$ & \\
\hline It is a barrier for teacher candidates & 60 & 95.2 & 29 & 78.3 & 89 \\
\hline It is an opportunity for teacher candidates & 3 & 4.8 & 8 & 21.7 & 11 \\
\hline
\end{tabular}


appointed as a teacher after graduating from 4 - 5 years of university education” which is asked to candidate teachers in order to learn their opinions on necessity of exam, while 65\% of them said "The examination is not necessary" (Table 3).

Data on this question prove that most of pre-service teachers do not consider KPSS examination necessary in teacher selection process. Candidates explain their views with comments like "The examination is not appropriate to evaluate the qualification of pre-service teachers" and "States does not trust in its own universities on the issue of raising teachers equipped with necessary information”.

\subsection{Comments of Sufficiency and Reliability of KPSS}

Aim of selection process of reliable teachers must be to choose right person with necessary skills (Karaca, 2011). The exam which aims to choose the right people to be appointed should have necessary scope, reliability. Within the scope of this study, pre-service teachers were asked "As a teacher candidate, do you believe KPSS has enough reliability?” and $82 \%$ said the exam was not reliable, $10 \%$ reliable but not enough, while $8 \%$ said the exam was reliable (Table 4).

Data obtained in this section of study prove that, most of pre-service teachers do not consider KPSS examination reliable. Candidates underline their reasons as stealing of questions in some examinations executed by the Institution and claims and allegations of cheating. Addition to those, many candidates believe that there have been corruptions in the appointment processes for several pre-service teachers. Opinions of some pre-service teachers are given below:

"I do not believe the exam is reliable (laughing). There are so many certain cases of corruption. I think nobody trusts that exam." (STUDENT 41)

"I do not believe the distribution of questions is fair. Besides, most of the questions are based only on memorizing skills. It is very hard to make right choice with such exam...” (STUDENT 11)

\subsection{Comments on Effect of KPSS on Teaching Life}

Since KPSS is an examination is applied for choosing teachers, the examination is expected to choose candidates equipped with necessary skills and equipments. Thus, the knowledge and information candidates get through preparation for this exam, should serve for their future careers. Within this scope, candidates were asked “Do you believe KPSS will serve you in your future teaching career?” 59\% of candidates answered "Examination is not useful for my teaching life", while 35\% said "Exam is useful for my teaching life”. 6\% of candidates were hesitant. Answers of the candidates are given in Table 5 due to their sub themes.

Data gathered in this section of study prove that many of the candidates believe preparation process for KPSS and information and knowledge they get in this process will not contribute to their careers and experience in their teaching lives. Candidates say that most of information they get during preparation process is based on memorizing and most of them are not useful for their future. Comment of one of the candidates is given below:

"I do not believe most of the subjects I am studying now will be useful after the examination. Yes, some information can be considered important for general culture but this is not a return of my efforts... If I could have transferred this effort to some other subject, I believe I could have reached to better results." (STUDENT 66)

Table 3. Comments of pre-service teachers on necessity of KPSS.

\begin{tabular}{|c|c|c|c|c|c|}
\hline \multirow{2}{*}{ Sub-themes } & \multicolumn{2}{|c|}{ Girls } & \multicolumn{2}{|c|}{ Boys } & \multirow{2}{*}{$\begin{array}{c}\text { Total } \\
\%\end{array}$} \\
\hline & $\mathrm{n}$ & $\%$ & $\mathrm{n}$ & $\%$ & \\
\hline Exam is necessary & 22 & 35 & 13 & 35 & 35 \\
\hline Exam isn't necessary & 41 & 65 & 24 & 65 & 65 \\
\hline
\end{tabular}

Table 4. Comments on pre-service teachers on sufficiency and reliability of KPSS.

\begin{tabular}{|c|c|c|c|c|c|}
\hline \multirow{2}{*}{ Sub-themes } & \multicolumn{2}{|c|}{ Girls } & \multicolumn{2}{|c|}{ Boys } & \multirow{2}{*}{$\begin{array}{c}\text { Total } \\
\%\end{array}$} \\
\hline & $\mathrm{n}$ & $\%$ & $\mathrm{n}$ & $\%$ & \\
\hline Exam is reliably & 3 & 4.7 & 5 & 13.5 & 8 \\
\hline Exam isn’t reliably & 52 & 82.5 & 30 & 81 & 82 \\
\hline Exam is reliably but it's not sufficient & 8 & 12.6 & 2 & 5.4 & 10 \\
\hline
\end{tabular}


Table 5. Comments of pre-service teachers on effects of KPSS on their teaching lives.

\begin{tabular}{|c|c|c|c|c|c|}
\hline \multirow{2}{*}{ Sub-themes } & \multicolumn{2}{|c|}{ Girls } & \multicolumn{2}{|c|}{ Boys } & \multirow{2}{*}{$\begin{array}{c}\text { Total } \\
\%\end{array}$} \\
\hline & $\mathrm{n}$ & $\%$ & $\mathrm{n}$ & $\%$ & \\
\hline Exam is helpful & 29 & 46 & 6 & 16.2 & 35 \\
\hline Exam isn't helpful & 32 & 50.7 & 27 & 73 & 59 \\
\hline Undecided & 2 & 3 & 4 & 10.8 & 6 \\
\hline
\end{tabular}

Table 6. Comments of pre-service teachers on distribution of questions in KPSS.

\begin{tabular}{|c|c|c|c|c|c|}
\hline \multirow{2}{*}{ Sub-themes } & \multicolumn{2}{|c|}{ Girls } & \multicolumn{2}{|c|}{ Boys } & \multirow{2}{*}{$\begin{array}{c}\text { Total } \\
\%\end{array}$} \\
\hline & $\mathrm{n}$ & $\%$ & $\mathrm{n}$ & $\%$ & \\
\hline Distribution of questions are suitable & 20 & 31.7 & 18 & 48.6 & 38 \\
\hline Distribution of questions aren't suitable & 43 & 68.2 & 19 & 51.4 & 62 \\
\hline
\end{tabular}

\subsection{Comments on Distribution of Questions in KPSS}

Having necessary and qualified knowledge on branch is of course one of the main conditions to become a good teacher. Besides, due to their place in society, teachers are expected to have information on several different disciplines. From this point of view, pre-service teachers were asked "Dou think question areas in KPSS (general skills, general culture, educational sciences, branch information) are appropriate?” $62 \%$ of the candidates do not find question areas appropriate while 38\% said they found question areas appropriate (Table 6).

Data prove that pre-service teachers do not consider distribution and scope of questions of KPSS exam are appropriate. Candidates made several comments on distribution and scope of questions. Most common comments are "There should be a section for the branch of the candidate in exam", "Pre-service teachers should be selected with interviews", "Communication and talking skills of the candidate teachers should be evaluated", "Exam should include application of teaching skills". Here are some of the comments of pre-service teachers on the issue:

"Distribution of questions is fine to me. I think a teacher should have information on Turkish, history, citizenship and so on at a certain level... I think there should be less questions based on memorizing..." (STUDENT 83)

"I believe distribution of questions is unfair. As a teacher of biology, I believe I do not have to know that much of history or geography. I am forced to study on subjects of other teachers' proficiency." (STUDENT 67)

\section{Discussion}

The aim of this study is to determine the views of candidate teachers who study at education faculties on Public Personnel Selection Examination (KPSS). Thus, opinions of senior students of education faculties are tried to be evaluated and results given below are found:

Most of the candidate teachers who participated to this study believe that private education institutions are more beneficial for the preparation process of KPSS. They believe that private education institutions encourage organized study and since they need popularity and advertisement, they focus on students' success. Besides, some of the candidate teachers believe school is more beneficial. The main reason why private education institutions are accepted more beneficial than schools for KPSS preparation is that there are no lectures on general skills and general culture in schools. According to the study of Sezgin and Duran [14] on 47 pre-service teachers who have just graduated from university and attended to KPSS examination, they came up with conclusion that $40 \%$ of pre-service teachers did not find going to private education institutions necessary. Results of that study do not match with the results of this study in terms of necessity of private education institutions in KPSS preparation process.

Results of this study show that many pre-service teachers consider the exam as an obstacle on their ways to become teachers. Candidates believe that, this exam is far from choosing the right person and candidates with memorizing skills become successful and advanced. Among pre-service teachers, there are also candidates who think this exam is an opportunity of recognition. Addition to those, pre-service teachers have negative thoughts on the necessity of KPSS. They do not believe they need to attend such exam to be appointed as teachers after 
graduating from 4 - 5 years of faculties. Candidates consider attending to such exam for evaluation of their knowledge and skills as an irrespective behavior, also it shows that state does not trust its own universities. According to the study of Karaca [11], pre-service teachers give so little support to the necessity of KPSS examination. Results of that study match with the results of this study in this aspect.

Many of the pre-service teachers give negative feedbacks on the reliability of the examination. They show the recently increasing cheating and corruption claims as evidence. They also mention that since the exam is executed one or two times in a year, factors like mood, accidents and chance also negatively affect the solution. Also, many of the pre-service teachers mentioned that subjects and information they studied on for the preparation of exam would not be useful in their future teaching careers. Candidates said most of the information they used in the exam were actually based on memorizing skills and thus would not be beneficial in the coming years. Candidates also believe that, an exam without the stage of application would not contribute to their career. In the studies of Nartgün [15] Y1lmaz [16] and Sezgin and Duran [14], it is mentioned that KPSS is not an effective tool for selecting right candidates who can perform teaching profession, it cannot be considered as an effective tool in teachers appointment process, since pre-service teachers are selected with KPSS exam based on memorizing skills, it also encourages students to an education method of memorizing, it forces candidates to ignore many of lectures including practice and have to focus more on theoretically subjects. Results of those studies match with the results of this study.

\section{Conclusion}

Results of this study show that pre-service teachers do not see the distribution of questions in KPSS appropriate. Candidates prefer an exam including practices and test of knowledge on their professional areas rather than an exam composed of questions testing their memorizing skills. In the study of Eraslan [9], candidate teachers demand their entry scores to faculty and education points have to be taken into account while appointing and selecting teachers. Results of that study have similarities with the results of this study.

\section{Recommendations}

Evaluating the results of this study both in general and within the framework of all sub problems, it is obvious that, pre-service teachers do not have very positive thoughts on KPSS examination. Candidates consider examination as an obstacle on their ways to become a teacher and believe that exam is not an appropriate and enough tool for selecting right people. Candidates also agree that a kind of examination is necessary since there are too many graduates and there are not enough employment positions to meet needs of all those graduates.

In this direction, attending of graduated pre-service teachers to an exam composed of theory and practice stages rather than attending to KPSS seems like a better option for effective selecting of teachers and this seems it can meet the needs of many candidate teachers. Teacher selecting processes of Britain and France are better examples of selecting candidates. In Britain, teachers are selected due to interviews of schools they applied to [17], while in France they attend to exam organized by Teacher raising Institutes which are established in the organizational framework of each university. This selection method is composed of a written exam that evaluates information of area as well as an interview testing candidates' ability of communication, presentation and their attitudes to teaching as a profession [18].

\section{References}

[1] Gündoğdu, K., Çimen, N. and Turan, S. (2008) Öğretmen Adaylarının Kamu Personeli Seçme Sınavına (KPSS) İlişkin Görüşleri. (Teachers Candidates’ Opinions toward Civil Servant Selection Exam.) Ahi Evran Üniversitesi Kirşehir Eğitim Fakültesi Dergisi (KEFAD), 9, 35-43.

[2] Erden, M. (2005) Öğretmenlik mesleğine giriş. (Introduction to Teaching Profession.) Alkım Yayınları, İstanbul.

[3] Uçan, A. (2007) Türkiye'de öğretmenlik mesleğinin tarihçesi. (History of Teaching Profession in Turkey.) http://www.ogretmen.info/ogretmenlik_tarihce_.asp

[4] Tan, H. (1989) Türk Eğitiminde Kalite Sorunu. (Quality Problems in Turkish Education System.) M. ̈̈. Eğitim Bilimleri Dergisi, 1, 129-142.

[5] Milli Eğitim Bakanlığı (Ministry of Education) (1982) Öğretmen Yetiştirmede Koordinasyon. (Coordination in Teachers’ Education.) MEB yayınları, Ankara. 
[6] Akyüz, Y. (1999) Türk Eğitim Tarihi. (History of Turkish Education System.) Kültür Koleji Yayınları İstanbul, Turkey.

[7] Semerci, N. and Özer, B. (2005) Tezsiz yüksek lisans ve üniversite son sınıf öğrencilerinin KPSS sınavına yönelik algıları. (Graduate and Undergraduate Students’ Perception toward Civil Servant Selection Exam.) XIV. Eğitim Bilimleri Kongresi’nde sözlü olarak sunulan bildiri. Pamukkale Üniversitesi, Denizli.

[8] Dilekmen, M., Ercoşkun, M.H. and Nalçacı, A. (2005) Öğretmen Adaylarının Akademik ve KPSS Başarılarının Çeşitli Değişkenler Açısından İncelenmesi. (Investigation on Academic and Selection Exam Achievement of Teachers Candidates.) Kazım Karabekir Ĕgitim Fakültesi Dergisi, 11, 304-315.

[9] Eraslan, L. (2006) Öğretmenlik Mesleğine Girişte Kamu Personeli Seçme Sınavı (KPSS) Yönteminin Değerlendirilmesi. (Evaluation of Civil Servant Selection Exam in Entering of Teaching Profession.) Uluslararası Insan Bilimleri Dergisi, 1, 1-31.

[10] Karaçanta, H. (2009) Öğretmen Adayları için Kamu Personeli Seçme Sınavı Kaygı Ölçeğinin Geliştirilmesi. (Geçerlik ve güvenirlik çalışması.) (Development of Civil Servant Selection Exam Anxiety Scale and It’s Reliability and Validity.) Gazi Üniversitesi Endüstriyel Sanatlar Ë̆itim Fakültesi Dergisi, 25, 50-57.

[11] Karaca, E. (2011) Öğretmen Adaylarının Kamu Personeli Seçme Sınavı’na (KPSS) Yönelik Tutumları. (Teachers Candidates' Perceptions toward Civil Servant Selection Examination.) Akademik Bakış Dergisi, 23, 1-18.

[12] Ölçme Seçme ve Yerleştirme Merkezi (Evaluation, Selection and Placement Center) ÖSYM (2015) Civil Servant Selection Exam Guide. http://dokuman.osym.gov.tr/pdfdokuman/2015/KPSS/KPSSLISANSKILAVUZU20150522.pdf

[13] Yıldırım, A. and Şimşek, H. (2005) Sosyal Bilimlerde Nitel Üraştırma Yöntemleri. (Qualitative Research Methods in Social Sciences.) Seçkin Ankara, Turkey.

[14] Sezgin, F. and Duran, E. (2011) Kamu Personeli Seçme Sınavı'nın (KPSS) Öğretmen Adaylarının Akademik ve Sosyal Yaşantılarına Yansımaları. (Effects of Civil Servant Selection Exam on Academic and Social Lives of Teachers Candidates.) TSA, 15, 9-22.

[15] Nartgün, Ş.S. (2008) Aday Öğretmenlerin Gözüyle Millî Eğitim Bakanlığına Bağlı Eğitim Kurumlarına Öğretmen Atama Esaslar1. (Teachers' Point of Views about Teachers Selection System of Ministry of Education in Turkey.) Abant İzzet Baysal Üniversitesi Ĕ̈itim Fakültesi Dergisi, 8, 47-58.

[16] Yılmaz, K. (2010) Sosyal Bilgiler Eğitimindeki Sorunlar ve Çözüm Önerileri: Öğretim Elemanlarının Görüşleri. (Problems and Recommendations toward Social Sciences Education: Lecturers’ Point of Views.) Türk Eğitim Bilimleri Dergisi, 8, 839-867.

[17] Dilaver, H. (1996) Türkiye'de öğretmen istihdamının dünü, bugünü ve yarını: Eğitimimize bakışlar. (Teachers’ Employments in Turkey: Yesterday, Today and Tomorrow.) Kültür Koleji Eğitim Vakfi Yayınları. İstanbul, Turkey.

[18] Demir, M.C. and Gür, H. (2000) Türkiye, İngiltere ve Fransa'da İşe Alınma, Çalışma Hayatı ve Ücret Politikaları Açısından Öğretmenin Durumu. (Employment, Salary and Working Conditions of Teachers in Turkey, England and France.) II. Ulusal Öğretmen Yetiştirme Sempozyumu, Çanakkale, 10-12 Mayıs. 